\title{
Development of Probiotic “creamy requeijão" Formulations Containing Lactobacillus Strains
}

\author{
Viviane Lívia C. Souza ${ }^{1}$, Moysés Estevão S. F. Pehrson ${ }^{1} \&$ Ismael M. Mancilha ${ }^{1}$ \\ 1Escola de Engenharia de Lorena, University of São Paulo, Lorena, SP, Brazil \\ Corresponding author: Viviane Lívia C. Souza, Escola de Engenharia de Lorena, Department of industrial \\ biotechnology, Universidade de São Paulo São Paulo, Lorena, CEP 12600-970, Brazil. Tel: 55-12-991-276-738. \\ E-mail: liviacarvalho@usp.br
}

$\begin{array}{lc}\text { Received: March 6, } 2019 & \text { Accepted: March 25, } 2019 \quad \text { Online Published: April 30, } 2019 \\ \text { doi:10.5539/jfr.v8n3p86 } & \text { URL: https://doi.org/10.5539/jfr.v8n3p86 }\end{array}$

\begin{abstract}
Functional foods, with emphasis on probiotics, are products that, besides possessing adequate nutritional value, stimulate physiological and metabolic activities in the body. Thus, these benefits combined with greater awareness of the population in the search for food reeducation boost the consumption of this kind of food. "Creamy requeijão" is a dairy derivative that has a matrix with physicochemical characteristics suitable for its use as a potential carrier of probiotic microorganisms. Thus, this study aimed to the evaluation of probiotic "creamy requeijão" formulations containing, individually six Lactobacillus strains, as follows: L. plantarum ATCC 8014, L. acidophilus ATCC 4356, L. delbrueckii UFV H2B20, L. fermentum ATCC 9338, L. casei ATCC 7469 and $L$. paracasei SP11. The results revealed that during the storage of the formulations for a period of 65 days at $5{ }^{\circ} \mathrm{C}$ the cells remained viable at levels above $10^{8} \mathrm{CFU} . \mathrm{g}^{-1}$, which allows to classify these formulations as functional foods. In addition, the consumption of only $1 \mathrm{~g}$ per day of this food would be enough to attend the requirements of Brazilian legislation regarding the consumption of food with probiotic claims.
\end{abstract}

Keywords: functional foods, lactic acid bacteria, dairy products

\section{Introduction}

Probiotics are defined as "living microorganisms which, when consumed in adequate amounts, confer health benefits to the host by modulating the microbiota and preventing infection" (FAO, 2002). Besides promoting the maintenance of a healthy gastrointestinal tract microbiota, they confer resistance to colonization by pathogens, as well as help in the lactose digestion in intolerant individuals and promote activation of the immune system (Kechagia et al., 2013; Kerry et al., 2018). Dairy products are the main vehicles of probiotic microorganisms, being the pioneers in this category (Sanchez et al., 2009). The global market for probiotics was valued at $\$ 42.66$ billion in 2016 and some projections indicate that this sector could reach \$ 64 billion in 2022 (www.marketsandmarkets.com).

Several functional foods can be found currently in the market. Fermented milks and yogurts are the most traditional, but the development of probiotic cheeses have been highlighted, because it is a matrix that presents higher fat content and higher $\mathrm{pH}$. These characteristics favor the maintenance of microorganism integrity during food storage and in its passage through the gastrointestinal tract (Stanton et al., 1998; Kechagia et al., 2013). In this context, "creamy requeijão", which is a typical Brazilian dairy product accepted by the population, has not been explored yet as a vehicle for probiotic microorganisms. According to the Pattern of Identity and Quality of "creamy requeijão" (PIQ), this food must present at least 55\% of fat in the dry extract and the maximum of $65 \%$ of moisture (Brazil, 1997).

The probiotics microorganisms commonly found in commercial formulations comprise lactic acid species belonging to the genera Lactobacillus, Bifidobacterium, Streptococcus and Enterococcus, as well as yeasts such as Saccharomyces boulardii (Kerry et al., 2018). In this scenario, the use of Lactobacillus species in the human diet is relevant since the beginning of the 20th century, being considered a promising group of microorganisms for the formulation of probiotic foods (Stiles \& Holzapfel 1997; Singh et al., 2011).

The National Agency of Sanitary Vigilance in Brazil recommends that, in order to ensure the beneficial effect of probiotics, a minimum of viable cells of these microorganisms should be consumed in the range of $10^{8}$ to $10^{9}$ 
CFU.g ${ }^{-1}$ per day (Brazil, 2008). On the other hand, the International Association of Probiotics (2000) recommends that daily intake of these functional foods should be equal to or greater than $10^{7} \mathrm{CFU} . \mathrm{g}^{-1}$. However, the Brazilian Normative Instruction No. 28/2018 does not establish maximum or minimum levels regarding the concentration of viable cells per gram in this sort of products (Brazil, 2018).

Studies involving the incorporation of probiotic microorganisms into different food categories have been developed with emphasis on goat milk ice cream supplemented with $L$. acidophilus, and B. lactis (Akalin et al., 2018), chocolates containing $L$. paracasei and $L$. acidophilus containing prebiotic carbohidrate such as inulin (Konar et al., 2018); Minas cheese containing L. acidophilus LA 14,,and B. longum BL 05 (Lollo et al. , 2015) and cream cheese containing B. animalis subsp. lactis DSM 10140, and L. reuteri DSM 20016 (Speranza et al., 2017). In these studies, the authors considered the mentioned foods as suitable matrices for incorporation and maintenance of probiotic species.

Considering the characteristics of "creamy requeijão" as a vehicle for probiotic microorganisms, based on the consumer's acceptance of this product and the consumer interest regarding functional foods, the present study aimed to evaluate the development of a probiotic "creamy requeijão" formulation containing different Lactobacillus species, considering the cell maintenance when the product was stored for 65 days $/ 5^{\circ} \mathrm{C}$, as well as its physicochemical composition.

\section{Material and Methods}

\subsection{Micro-organisms and Inoculum Preparation}

Six Lactobacillus strains were evaluated, consisting of: L. plantarum ATCC 8014, L.acidophilus ATCC 4356, L. delbrueckii UFV H2B20, L. fermentum ATCC 9338, L. casei ATCC 7469 and L. paracasei SP11 (Nestlé), maintained at $-20{ }^{\circ} \mathrm{C}$ in glycerol $20 \%(\mathrm{v} / \mathrm{v})$. The activation of these strains was performed by inoculating $2 \mathrm{~mL}$ of the stock cultures in $198 \mathrm{ml}$ of Man Rogosa \& Sharpe - MRS medium (De Man, Rogosa \& Sharpe, 1960) previously sterilized, followed by incubation for $24 \mathrm{~h}$ at $37^{\circ} \mathrm{C}$. Subsequently, successive replications were performed in order to obtain a higher inoculum volume, followed by concentration of the cells so that a high amount of Lactobacillus could be reached in a small volume of inoculum. The cells were then suspended in $50 \mathrm{ml}$ of reconstituted skim milk (10\%) and transferred to two sterile Erlenmeyer flasks, followed by incubation at $37^{\circ}$ $\mathrm{C}$ for $2 \mathrm{~h}$, following methodology proposed by Drunkler (2009), with adaptations.

\subsection{Preparation of Probiotic "creamy requeijão" Formulations}

The probiotic "creamy requeijão" was prepared by taking $9 \mathrm{~L}$ of pasteurized milk ( $3 \%$ fat) heated to $82{ }^{\circ} \mathrm{C}$ and added with $85 \%$ food grade lactic acid (Purac), diluted (1:10), with slow stirring until coagulation was observed. Afterwards, the clotted milk was cooled at room temperature $\left(23 \pm 2{ }^{\circ} \mathrm{C}\right)$, and the curd was separated and pressed in a properly hygienized nylon sieve. Butter cream was then added to this curd, in amount equivalent to $50 \%$ of its weight, followed by manual homogenization and heating to $85^{\circ} \mathrm{C}$. After, sodium chloride $(1.3 \% \mathrm{w} / \mathrm{w})$ sodium citrate and polyphosphates $\left(1 \%(\mathrm{w} / \mathrm{w})\right.$, diluted in water at $80^{\circ} \mathrm{C}$, were added, followed by homogenization for approximately $5 \mathrm{~min}$ and cooling at $50^{\circ} \mathrm{C}$.

The obtained product was then characterized regarding its physicochemical properties, and a fraction of it was used to incorporate the Lactobacillus strains, and then evaluated regarding its microbiological aspects, and cell viability.

One portion of the product (control) was packed while still hot in a properly sterilized polypropylene pot, sealed with PVC film (Wyda Pratic), and stored at $5 \pm 1{ }^{\circ} \mathrm{C}$. The remaining product was cooled to $50^{\circ} \mathrm{C}$ and portioned in 6 fractions. Each fraction was inoculated, individually, with Lactobacillus strains according to methodology described by Drunkler (2009), in order to get an initial cell concentration of approximately $10^{10}$ to $10^{13} \mathrm{CFU} \cdot \mathrm{g}^{-1}$ followed by cooling and stored at $5 \pm 1{ }^{\circ} \mathrm{C}$. Samples of each one were collected after 7, 30, 45 and 65 days for characterization.

\subsection{Analytical Methods}

\subsubsection{Determination of Cellular Viability}

The population of viable cells (CFU.g ${ }^{-1}$ ) in the samples of potential probiotic "creamy requeijão", was determined by pour plate method, as described by Silva, Junqueira \& Silveira (2001).

\subsubsection{Determination of $\mathrm{pH}$, Titratable Acidity, and Lipid Content}

The $\mathrm{pH}$ was determined by the electroanalytical method in digital $\mathrm{pH}$ meter (GEHAKA® PG1800) employing 2 $\mathrm{g}$ of sample at room temperature $\left(23,0 \pm 2,0^{\circ} \mathrm{C}\right)$ diluted in $20 \mathrm{~mL}$ of water. The titratable acidity, expressed as lactic acid (\%), and the lipid content was determined according to Zenebon et al (2008). 


\subsubsection{Determination of Total Dry Extract (TDE) and Fat Content in Dry Extract (FDE)}

The TDE and FDE content in the "creamy requeijão" was determined by drying $3 \mathrm{~g}$ of the samples in a microwave oven (Brastemp mod. BMP 40E SAAB), according to the methodology described by Van Dender (2000).

\subsection{Microbiological Analyzes}

Microbiological characterization of the samples was performed, in relation to the presence of total and thermotolerant coliforms, Staphylococcus spp and Salmonella, according to Silva (2001).

\section{Results and Discussion}

\subsection{Characterization of "cream requeijão" Regarding the Cellular Viability}

The results showed in Figure 1 demonstrate that the populations of the strains L. plantarum ATCC 8014, $L$. delbrueckii UFV H2B20 and L. fermentum ATCC 9338 decreased 3,0 log cycles when the respective formulations were stored at $5{ }^{\circ} \mathrm{C}$ for 65 days. On the other hand, formulations containing the strains $L$. casei ATCC 7469, L. paracasei SP11 and L. acidophilus ATCC4356 showed a decrease of only one cycle under the same conditions.

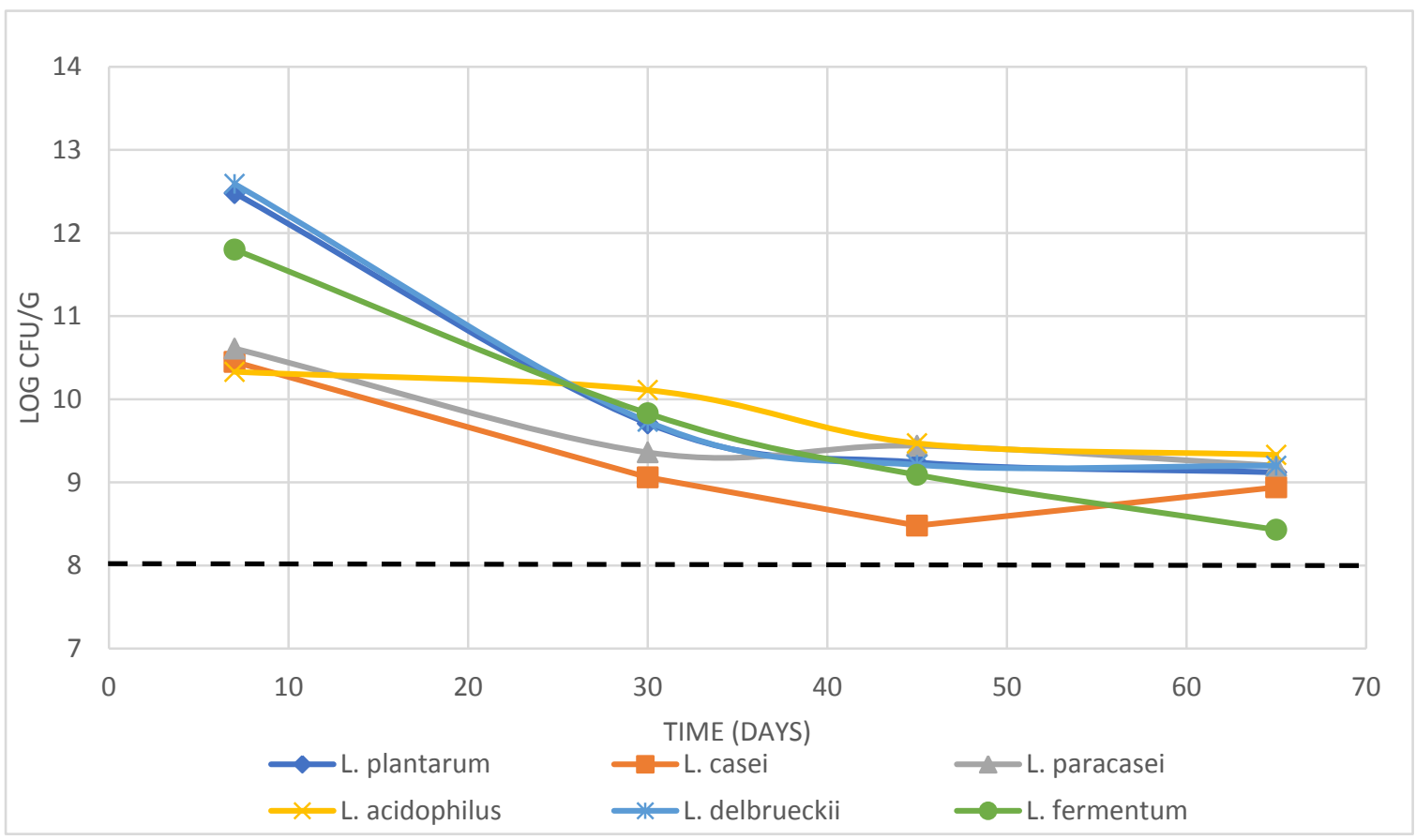

Figure 1. Profile of the Lactobacillus strains viability in "creamy requeijão" storaged for 65 days at $5{ }^{\circ} \mathrm{C}$. Dashed line corresponds to the minimum amount of probiotic cells to be consumed according to Brazilian law

According to Saad, Cruz \& Faria (2011) there are factors that may interfere in the survival of probiotic strains, incluiding the quality of the raw material (considering that milk may contain residues of antibiotics and pesticides and its $\mathrm{pH}$, lipid and salt content), as well as the strain used and storage conditions, such as temperature and oxygen level in the medium.

The results obtained in the present study are similar to those reported by Speranza et al (2017) in their research with cream cheese formulations supplemented with Bifidobacterium animalis subsp. yactis DSM 10140 and $L$. reuteri DSM 20016, stored for 28 days at $4^{\circ} \mathrm{C}$. These results demonstrate the potential of dairy products as a matrix for carrying probiotic microorganisms.

On the other hand, lower results were reported by Konar et al (2018) studying sugarless white chocolate as a matrix, inoculated with a $L$. paracasei strain, showing that the initial cell concentration was $10^{9} \mathrm{CFU} \cdot \mathrm{g}^{-1}$, and after 60 days storage at room temperature, the population decreased to $10^{6} \mathrm{CFU} \cdot \mathrm{g}^{-1}$. The authors pointed out that this result should be due to the low water activity in the matrix studied. Similarly, Teixeira (2012), studying "creamy requeijão" containing L. acidophilus and B. bifidum, reported that these strains were maintained at 
stable viability levels after storage for 15 days at $10^{\circ} \mathrm{C}$. After this period there was a decrease in the Lactobacillus population, equivalent to two log cycles, reaching a cell population of $4.0 \times 10^{7} \mathrm{CFU} . \mathrm{g}^{-1}$, and $2.0 \times 10^{8} \mathrm{CFU} . \mathrm{g}^{-1}$ of B. bifidum. The incorporation of Bifidobacterium animalis subsp. Lactis Bb-12 and prebiotic compounds (inulin and oligofructose) in "creamy requeijão" formulations were also evaluated by Drunkler, (2009), and the results showed that the cells remained viable at about $10^{6} \mathrm{CFU} . \mathrm{g}^{-1}$ for 60 days storage.

However, regarding the daily intake of probiotic foods, it should be emphasized that is necessary to consume $10^{6-7} \mathrm{CFU}$. $\mathrm{g}^{-1}$, which is contained in $100 \mathrm{~g}$ of the product, according to the National Agency of Sanitary Vigilance recommendation (Brazil, 2008). Therefore, it becomes unfeasible, considering that the average "creamy requeijão" consumption by the population is $30 \mathrm{~g}$ per day. In this context, it is worth mentioning that in only $1 \mathrm{~g}$ of the different formulations evaluated in the present work was verified a viable cell population greater than $10^{8} \mathrm{CFU}$ after 65 days of storage at $5{ }^{\circ} \mathrm{C}$. This result demonstrates the technical feasibility of using "creamy requeijão" as a vehicle of the probiotic strains.

"Creamy requeijão" is a product of high acceptance in the different social classes in Brazil, so it can easily be inserted into the daily diet of the population, with an additional benefit of having the probiotics in its formulation. Therefore, it can contribute to the gastrointestinal health of consumers, and presents potential to be marketed, due to the benefits on daily consumption of functional foods.

\subsection{Phisicochemical Characterizations of the "creamy requeijão" Formulations}

As showed in Table 1, the $\mathrm{pH}$ values in the probiotic "creamy requeijão" ( $6.20 \pm 0.10$ to $6.70 \pm 0.13)$ were lower than the control formulation ( $6.44 \pm 0.17$ to $6.73 \pm 0.18$ ), after the storage for 65 days at $5{ }^{\circ} \mathrm{C}$.

Table 1. $\mathrm{pH}$ values and standard deviation of the probiotic "creamy requeijão" formulations evaluated during 65 days at $5^{\circ} \mathrm{C}$

\begin{tabular}{cccccccc}
\hline & \multicolumn{7}{c}{ Formulations } \\
\hline Time (days) & Control & LP & LC & LI & LA & LD & LF \\
\hline 7 & $6.65 \pm 0.18$ & $6.40 \pm 0.16$ & $6.44 \pm 0.19$ & $6.40 \pm 0.16$ & $6.41 \pm 0.17$ & $6.20 \pm 0.10$ & $6.22 \pm 0.19$ \\
30 & $6.73 \pm 0.18$ & $6.49 \pm 0.17$ & $6.30 \pm 0.17$ & $6.42 \pm 0.18$ & $6.39 \pm 0.15$ & $6.22 \pm 0.15$ & $6.40 \pm 0.19$ \\
45 & $6.44 \pm 0.17$ & $6.51 \pm 0.19$ & $6.39 \pm 0.10$ & $6.70 \pm 0.13$ & $6.46 \pm 0.18$ & $6.32 \pm 0.16$ & $6.52 \pm 0.17$ \\
65 & $6.51 \pm 0.19$ & $6.58 \pm 0.13$ & $6.44 \pm 0.12$ & $6.69 \pm 0.15$ & $6.54 \pm 0.11$ & $6.41 \pm 0.19$ & $6.69 \pm 0.14$ \\
\hline
\end{tabular}

LP = Lactobacillus plantarum ATCC 8014; LC= Lactobacillus casei ATCC 7469; LI= Lactobacillus paracasei SP11; LA= Lactobacillus acidophilus ATCC 4356; LD= Lactobacillus delbrueckii UFV H2B20; LF= Lactobacillus fermentum ATCC 9338.

Drunkler (2009) reported that the $\mathrm{pH}$ decreased was not significantly altered ( $\mathrm{p}>0.05)$ in symbiotic "creamy requeijão" formulations in relation to control formulation after 60 days of storage at $5^{\circ} \mathrm{C}$. This observation was also verified in the present work, where the $\mathrm{pH}$ values after 65 days of the control formulation $(6.51 \pm 0.19)$ and the respective probiotic formulations remained between $6.41 \pm 0.19$ to $6.69 \pm 0.15$.

The results in Table 2 show that the lactic acid content was higher in the formulations containing the Lactobacillus strains, ranging from $0.43 \%$ to $0.30 \%$ after 7 days at $5{ }^{\circ} \mathrm{C}$ and $0.28 \%$ at $0.24 \%$ after 65 days in relation to the control formulation ( $0.17 \%$ after 7 days at $5{ }^{\circ} \mathrm{C}$ and $0.12 \%$ after 65 days). This observation might be due to the production of lactic acid that occurred during the strains preactivation step in reconstituted milk at $10 \%$ at $37^{\circ} \mathrm{C}$ for $2 \mathrm{~h}$, prior to the inoculation in the curd.

Table 2. Values of lactic acid contents and standard deviation in the different probiotic "creamy requeijão" formulations stored for 65 days at $5{ }^{\circ} \mathrm{C}$

\begin{tabular}{cccccccc}
\hline & \multicolumn{7}{c}{ Formulations } \\
\hline Time (days) & Control & LP & LC & LI & LA & LD & LF \\
\hline 7 & $0.17 \pm 0.07$ & $0.35 \pm 0.08$ & $0.30 \pm 0.09$ & $0.38 \pm 0.08$ & $0.30 \pm 0.08$ & $0.43 \pm 0.09$ & $0.43 \pm 0.09$ \\
30 & $0.12 \pm 0.09$ & $0.23 \pm 0.09$ & $0.30 \pm 0.09$ & $0.32 \pm 0.09$ & $0.29 \pm 0.07$ & $0.23 \pm 0.08$ & $0.27 \pm 0.09$ \\
45 & $0.14 \pm 0.09$ & $0.26 \pm 0.08$ & $0.29 \pm 0.08$ & $0.33 \pm 0.09$ & $0.29 \pm 0.09$ & $0.26 \pm 0.09$ & $0.28 \pm 0.08$ \\
65 & $0.12 \pm 0.08$ & $0.25 \pm 0.09$ & $0.28 \pm 0.09$ & $0.24 \pm 0.08$ & $0.28 \pm 0.09$ & $0.28 \pm 0.09$ & $0.24 \pm 0.09$ \\
\hline
\end{tabular}

$\mathrm{LP}=$ Lactobacillus plantarum ATCC 8014; LC= Lactobacillus casei ATCC 7469; LI= Lactobacillus paracasei SP11; LA= Lactobacillus acidophilus ATCC 4356; LD= Lactobacillus delbrueckii UFV H2B20; LF= Lactobacillus fermentum ATCC 9338.

3.4 Moisture, Total Dry Extract and Fat in Dry Extract in Probiotic "cream requeijão" 
The results shown in Table 3 demonstrate that the content of fat in the dry extract, and the humidity of the "cream requeijão" formulations attend the minimum standard described in the Technical Regulation Administrative Rule 359 (Brazil, 1997). These values consist of fat content in the dry extract (FDE) should be higher than 55\% and the maximum Total Dry Extract (TDE) content of 65\%.

Table 3. Physicochemical characteristics of probiotic "creamy requeijão" formulations after 65 days at $5{ }^{\circ} \mathrm{C}$

\begin{tabular}{lccc}
\hline Formulation & Moisture (\%w/w) & TDE (\%w/w) & FDE (\%w/w) \\
\hline Control & 60.00 & 40.00 & 67.22 \\
L. acidophilus ATCC 4356 & 62.58 & 37.42 & 65.52 \\
L. plantarum ATCC 8014 & 62.00 & 38.00 & 63.81 \\
L. paracasei SP11 & 64.15 & 35.85 & 65.52 \\
L. casei ATCC 7469 & 64.95 & 35.05 & 66.30 \\
L. delbrueckii UFV H2B20 & 64.03 & 35.97 & 66.49 \\
L. fermentum ATCC 9338 & 63.45 & 36.55 & 65.82 \\
\hline
\end{tabular}

$\mathrm{TDE}=$ Total dry extract; FDE $=$ Fat in dry extract

\subsection{Microbiological Characterization of the Probiotic "creamy requeijão"}

The microbiological characterization of the different "creamy requeijão" formulations, stored for 65 days at $5^{\circ} \mathrm{C}$, reveals that all formulations are in agreement with the microbiological standards stablished in Technical Regulation - Administrative Rule 359 (Brazil, 1997).

\section{Conclusions}

In the present study, it has been demonstrated that "creamy requeijão" is a suitable vehicle for carrying strains of probiotic microorganisms without changing the characteristics of this dairy food. The formulations evaluated had a population above $10{ }^{8} \mathrm{CFU} \mathrm{g.}{ }^{-1}$ of viable cells after 65 days at $5{ }^{\circ} \mathrm{C}$. In this context, it is emphasized that the consumption of only $1 \mathrm{~g}$ of these formulations is enough to attend the daily intake requirements of products with probiotic claim, according to Brazilian law.

\section{Acknowledgments}

The present study was carried out at the Biotechnology Department of Escola de Engenharia de Lorena - USP SP - Brazil. The research was sponsored by CAPES.

\section{References}

Akalın, A. S., Kesenkas, H., Dinkci, N., Unal, G., Ozer, E., \& Kınık, O. (2018). Enrichment of probiotic ice cream with different dietary fibers: Structural characteristics and culture viability. J. Dairy Sci, 101, 37-46. https://doi.org/10.3168/jds.2017-13468.

Brasil (2006). Instrução Normativa nº 68, de 12 de dezembro de 2006, Ministério da Agricultura, Pecuária e Abastecimento. Dispõe dos Métodos Analíticos Oficiais Físico - Químicos, para Controle de Leite e Produtos Lácteos. Diário Oficial da União, Brasília (DF), de 14 de dezembro de 2006.

Brasil (1997). Portaria no 359, de 4 de setembro de 1997, Ministério da Agricultura, Pecuária e Abastecimento. Dispõe do Regulamento técnico para fixação de identidade e qualidade do requeijão cremoso ou requesón. Diário Oficial da União, Brasília (DF), de 04 de setembro de 1997.

Brasil (2008). Ministério da Saúde. Agência Nacional de Vigilância Sanitária. Comissões e Grupos de Trabalho. Comissão Técnico-científica de Assessoramento em Alimentos Funcionais e Novos Alimentos. Alimentos com Alegações de Propriedades Funcionais e ou de Saúde, Novos Alimentos/Ingredientes, Substâncias Bioativas e Probióticos. Retrieved from http://portal.anvisa.gov.br/alimentos/alegacoes

Brasil (2018). Instrução Normativa no 28, de 26 de julho de 2018, Ministério da Saúde. Ministério da Saúde. Agência Nacional de Vigilância Sanitária. Estabelece as listas de constituintes, de limites de uso, de alegações e de rotulagem complementar dos suplementos alimentares. Retrieved from http://portal.anvisa.gov.br/documents/10181/3898888/IN_28_2018_.pdf/84235aa6-978d-4240-bc02-1080a0 d2cbfd

De Man, J. C., Rogosa, M., \& Sharpe, M. E. (1960). A medium for the cultivation of lactobacilli. J. Applied Bact., 23, 130-135.

Drunkler, D. A. (2009). Produção de requeijão cremoso simbiótico. (Tese Doutorado em Tecnologia de 
Alimentos, Universidade Federal do Paraná, Curitiba, Brasil). Obtido em. Retrieved from http://www.posalim.ufpr.br/Pesquisa/pdf/DeisyADrunkler.pdf

FAO. (2002). Guidelines for the evaluation of probiotics in food. London, Ontario, Canada. Retrieved from https://www.who.int/foodsafety/fs_management/en/probiotic_guidelines.pdf

International Probiotics Association. (2017). The Global Voice of Probiotics. Retrieved from http://internationalprobiotics.org/wp-content/uploads/IPA-guidelines-to-qualify-a-microorganism-as-probiot ic-revised-aug-2017.pdf

Kechagia, M., Basoulis, D., Konstantopoulou, S., Dimitriadi, D., Gyftopoulou, K., Skarmoutsou, N., \& Fakiri, E. M. (2013). Health benefits of probiotics: a review. ISRN Nutrition, Article ID 481651. http://dx.doi.org/10.5402/2013/481651

Kerry, R. G., Patra, J. K., Gouda, S., Park, Y., Shin, H. S., \& Das, G. (2018). Benefaction of probiotics for human health: A review. Journal of food and drug analysis, 1-13. https://doi.org/10.1016/j.jfda.2018.01.002

Konar ,N., Palabiyikb, I., Tokerc, O. S., Polatd, D. G., Kellecid, B., Pirouziane, H. R., Akcicekc, A., \& Sagdicc, O. (2018). Conventional and sugar-free probiotic white chocolate: Effect of inulin DP on various quality properties and viability of probiotics. Journal of Functional Foods, 43, 206-213. https://doi.org/10.1016/j.jff.2018.02.016

Lollo, P. C. B., Morato, P. N., Moura, C. S., Almada, C. N., Feliciob, T. L., Esmerino, E. A., ... Cruz, A. G. (2015). Hypertension parameters are attenuated by the continuous consumption of probiotic Minas cheese. Food Research International, 76, 611-617. https://doi.org/10.1016/j.foodres.2015.07.015

Minim, V. P. R. (2013) Análise Sensorial. Estudos com consumidores (3nd ed.) Viçosa, MG: Editora UFV.

Probiotics Market by Application (Functional Food \& Beverages (Dairy, Non-dairy Beverages, Baked Goods, Meat, Cereal), Dietary Supplements, Animal Feed), Source (Bacteria, Yeast), Form (Dry, Liquid), End User (Human, Animal), and Region - Forecast to 2022. (2017). Report Code: FB 2269. Retrieved from https://www.marketsandmarkets.com/Market-Reports/probiotic-marketadvanced-technologies-and-globalmarket-69.html

Saad, S. M. I., Cruz, A. G., \& Faria, J. A. F. (2011). Probióticos e Prebióticos em Alimentos: Aspectos Tecnológicos, Legislação e Segurança no Uso. (2nh. ed.) São Paulo, SP: Varela.

Sanchez, B., Reyes-Gavilán, C. G. L., Margolles, A., \& Gueimonde, M. (2009). Probiotic Fermented Milks: present and future. International Journal of Dairy Technology, 62, 1-10. https://doi.org/10.1111/j.1471-0307.2009.00528.x

Sanchez, B., Reyes-Gavilán, C. G. L., Margolles, A., \& Gueimonde, M. (2009). Probiotic Fermented Milks: presente and future. International Journal of Dairy Technology, 62, 1-10. https://doi.org/10.1111/j.1471-0307.2009.00528.x

Silva, N., Junqueira, V. C. A., \& Silveira, N. F. A. (2001). Manual de métodos de análise microbiológica de alimentos. (2nd ed.) São Paulo, SP: Editora Livraria Varela.

Singh, k., Kallali, B., Kumar, A., \& Thaker, V. (2011). Probiotics: A review. Asian Pacific Journal of Tropical Biomedicine, 1(2), 287-290. https://doi.org/10.1016/S2221-1691(11)60174-3

Speranza, B., Campaniello, D., Monacis, N., Bevilacqua, A., Sinigaglia, M., \& Corbo, M. R. (2017). Functional cream cheese supplemented with Bifidobacterium animalis subsp. Lactis DSM 10140 and Lactobacillus reuteri DSM 20016 and prebiotics. Food Microbiology. https://doi.org/10.1016/j.fm.2017.11.001.

Stanton, C., Gardiner, G., Lynch, P. B., Collins, J. K., Fitzgerald, G., \& Rossa, R. P. (1998). Probiotic Cheese. Int. Dairy Journal, 8, 491-496. https://doi.org/10.1016/S0958-6946(98)00080-6

Stiles, M. E., \& Holzapfel, W. H. (1997). Lactic acid bacteria of foods and their current taxonomy. Int J Food Microbiol, 36,1-29. https://doi.org/10.1016/S0168-1605(96)01233-0

Teixeira, L. S. B. (2012) Qualidade e viabilidade de requeijão cremoso adicionado de Lactobacillus Acidophilus e Bifidobacterium Bifidum. Dissertation, Master in Nutrition, Universidade Federal do Pernambuco, Brazil.

Van Dender, A. G. F. (2000). Requeijão cremoso e outros queijos fundidos: aspectos de qualidade, processamento, rotulagem, legislação e mercado (2nd ed.) Campinas,SP: Setembro Editora.

Zenebon, O., Pascuet, N. S., \& Tiglea, P. (2005). Métodos químicos e físicos para análise de alimentos, 4th ed., 
São Paulo.

\section{Copyrights}

Copyright for this article is retained by the author(s), with first publication rights granted to the journal.

This is an open-access article distributed under the terms and conditions of the Creative Commons Attribution license (http://creativecommons.org/licenses/by/4.0/). 